\title{
SISTEM INFORMASI MANAJEMEN KEUANGAN PADA PT. HULU BALANG MANDIRI MENGGUNAKAN FRAMEWORK LARAVEL
}

\author{
${ }^{1}$ Bambang Hermanto, ${ }^{2}$ Machudor Yusman, ${ }^{3}$ Nagara \\ 1,2,3 Jurusan Ilmu Komputer FMIPA Universitas Lampung \\ Jalan Prof. Sumantri Brojonegoro No. 1 Bandar Lampung 35145 \\ ${ }^{1}$ bambang.hermanto@ fmipa.unila.ac.id, ${ }^{2}$ machudor@unila.ac.id, ${ }^{3}$ nagara987@gmail.com
}

\begin{abstract}
The rapid development of technology forces us to learn and adapt, especially in the field of information technology. Information technology makes information spread very fast and accurate. This makes information technology a very important role in the company's growth for various sector, especially financial information. On the other side, manual work that related to numbers have very big risk of miscalculations from the employees (human error) and takes a relatively longer time. With the development of the Financial Management Web Based Information System, it is expected to help companies manage their financial reports and make decisions based on financial data.

This research has successfully developed Financial Management Web Based Information System by implementing the Laravel framework. The conclusion of this research is the Financial Management Web Based Information System by implementing the Laravel Framework successfully built in accordance with the agreed design, proved by the results of the test as appropriate as had been expected.
\end{abstract}

Keywords: Financial management information system, laravel framework, website.

\section{PENDAHULUAN}

Teknologi di zaman yang modern ini sudah menjadi pendamping hidup bagi masyarakat modern. Dalam melakukan aktivitas sehari-hari masyarakat modern hampir tidak bisa lepas dari penggunaan teknologi. Salah satu penggunaan teknologi adalah penggunaan smartphone atau ponsel pintar. Di tahun 2016 jumlah pengguna ponsel pintar diperkirakan mencapai 2,1 miliar [9]. Sementara jumlah pengguna ponsel di seluruh dunia diperkirakan akan melampaui angka lima miliar pada tahun 2019. Smartphone digunakan mulai dari ber-sosial media, mencari hiburan seperti game, melakukan pekerjaan kantor, sampai mencari informasi dan berita. Indonesia adalah salah satu negara di Asia Tenggara dengan pertumbuhan internet paling cepat di dunia bersamaan dengan Singapura, Thailand, Vietnam, Filiphina, dan Malaysia [1]. Berkembangnya teknologi yang sangat cepat memaksa masyarakat modern untuk belajar dan menyesuaikan diri, khususnya di bidang teknologi informasi.

Teknologi informasi membuat akses informasi menjadi sangat cepat dan akurat. Informasi adalah data yang telah diklasifikasikan atau diolah atau diinterpretasikan untuk digunakan dalam proses pengambilan keputusan [7]. Hal ini membuat teknologi informasi sangatlah berperan penting dalam kemajuan perusahaan di berbagai bidang, bahkan hampir semua bidang. Pedagang makanan kaki lima pun dewasa ini sudah menggunakan media sosial seperti Instagram sebagai media promosi. Tak hanya Instagram, berbagai media sosial juga digunakan untuk menjalankan bisnis. Hal ini membuat 119 juta pengguna internet di Indonesia menjadi salah satu pengguna Facebook, Instagram, Twitter, dan WhatsApp tertinggi di dunia [1].

Teknologi informasi yang ada dalam suatu perusahaan dapat mempermudah karyawannya mengelola informasi yang dibutuhkan di perusahaan tersebut. Selain mempermudah, teknologi yang pas dan akurat akan membuat keuntungan besar untuk perusahaan, karena teknologi yang 
tepat dapat meningkatkan kinerja karyawannya. Dalam hal informasi misalnya. Jika penyajian informasi dalam suatu perusahaan dilakukan dengan baik, maka pengelolaan informasi oleh karyawan lainya di perusahaan juga akan semakin baik. Contoh pengelolaan informasi yang membutuhkan penyajian informasi yang baik adalah pengambilan keputusan. Pengambilan keputusan oleh pihak manajer adalah hal yang sangat penting untuk mengendalikan perusahaan, menyusun perencanaan kegiatan perusahaan, dan pertimbangan dan pertanggungjawaban pada pihak eksternal. Tentunya manajer di sebuah perusahaan tidak bekerja sendirian dalam hal ini. Manajer memperoleh segala informasi yang diperlukan untuk pengambilan keputusan dari perangkat-perangkat kerjanya. Perangkat kerja di perusahaan tersebut, menyediakan informasi yang sudah diolah dari kumpulan data-data yang diperoleh melalui proses kerja sehari-hari. Informasi yang dihasilkan pun beragam, tergantung pada data yang diolah, contohnya laporan laba rugi, perubahan modal, arus kas, dan neraca. Setelah data diolah menjadi sajian informasi, barulah manajer melakukan pengambilan keputusan berdasarkan informasi tersebut. Pengambilan keputusan (Decision Making) sangat berpengaruh pada keberlanjutan dan kemajuan perusahaan. Maka dari itu penyajian informasi pun menjadi hal yang perlu diperhatikan.

Salah satu informasi yang perlu dikelola oleh suatu perusahaan yaitu informasi keuangan. Laporan keuangan secara singkat diartikan sebagai gambaran tentang kondisi keuangan suatu perusahaan secara nyata atau sebenarnya. Laporan keuangan dalam suatu perusahaan digunakan untuk dasar pembuatan keputusan dalam perusahaan. Karena hal itu analisis laporan keuangan diperlukan untuk menerjemahkan informasi pada laporan keuangan.

Informasi keuangan menjadi salah satu hal yang sangat kritikal untuk perusahaan. Mulai dari penggajian, laporan laba rugi, neraca, laporan arus kas, laporan pemasukan harian, laporan pemasukan bulanan, dan laporan pengeluaran harian. sedikit kesalahan bisa saja mengakibatkan kerugian besar bagi perusahaan. Selain pekerjaan manual yang berhubungan dengan angka sangat berisiko dengan adanya kesalahan perhitungan karyawan (human error), perhitungan secara manual juga memakan waktu lebih banyak. Terdapat tiga cara untuk mengatasi hal ini, yaitu mengganti manusia, memodifikasi mesin yang ada, dan ambil tindakan untuk mengidentifikasi, menetapkan masalah, dan bertindak berdasarkan masalah yang ditemukan [3].

PT. Hulu Balang Mandiri merupakan perusahaan yang bergerak di bidang penyedia jasa tenaga kerja (outsourcing) di Bandar Lampung. Dalam sistem kerja ini, perusahaan penyedia jasa outsource melakukan pembayaran terlebih dauhulu kepada tenaga kerja. Selanjutnya mereka menagih ke perusahaan pengguna jasa mereka. Tenaga kerja yang disediakan di perusahaan ini adalah office boy, cleaning service, security, SPG(Sales Promotion Girl), kasir dan parking. Tenaga kerja outsourcing bekerja berdasarkan kontrak dengan perusahaan penyedia jasa outsourcing, bukan dengan perusahaan pengguna jasa.

Pekerjaan kantor di PT. Hulu Balang Mandiri sebagian besar masih dilakukan secara manual. Dalam bidang keuangan, proses pengelolaan keuangan seperti penggajian, laporan keuangan harian, laporan keuangan bulanan, dan proses manajemen keuangan lainnya dilakukan secara manual melalui Microsoft Excel di satu komputer kerja karyawan, sehingga untuk melihat segala informasi dan data keuangan yang ada, karyawan lain harus secara manual melihat ke komputer tersebut. Begitu pula dengan pengetikan laporan keuangan yang harus diketik ulang setiap pengerjaannya.

Berdasarkan masalah di atas, PT Hulu Balang Mandiri membutuhkan sebuah sistem untuk membantu proses pengelolaan keuangannya. Dengan adanya sistem manajemen keuangan ini, proses penulisan laporan keuangan seperti, pembuatan laporan laba rugi, pembuatan laporan harian, pembuatan laporan bulanan, penggajian karyawan, penggajian client, dan pendataan pendapatan dan pengeluaran yang sebelumnya dilakukan secara manual bisa dilakukan lebih 
mudah dan dengan risiko kesalahan yang lebih sedikit jika dibandingkan dengan proses kerja yang sebelumnya.

\section{TINJAUAN PUSTAKA}

\section{a. Pengertian Data}

Data adalah fakta mengenai objek. Data dinyatakan dengan nilai (angka, deretan karakter, atau simbol) [4]. Menurut pendapat lainnya, data adalah fakta tentang sesuatu di dunia nyata yang dapat direkam dan disimpan pada media komputer. Definisi di atas perlu diperluas untuk mencerminkan realitas yang ada saat ini. Dengan demikian pengertian data dapat diperluas menjadi: fakta, teks, grafik, suara video yang bermanfaat di lingkup pengguna [4].

\section{b. Pengertian Informasi}

Informasi adalah hasil pengolahan data yang diproses menjadi lebih berguna dan lebih berarti bagi yang menerimanya. Sumber dari informasi adalah data. Suatu informasi dapat dikatakan bernilai bila manfaatnya lebih efektif dibandingkan dengan biaya mendapatkannya. Kegunaan informasi adalah untuk mengurangi hal ketidakpastian di dalam proses pengambilan keputusan tentang suatu keadaan. Informasi yang digunakan di dalam suatu sistem informasi umumnya digunakan untuk beberapa kegunaan [4].

\section{c. Pengertian Sistem Informasi}

Sistem informasi dapat didefinisikan sekumpulan subsistem yang berkaitan satu dengan yang lain untuk mencapai tujuan yang sama [8].

\section{d. Pengertian Laporan Keuangan}

Laporan keuangan adalah catatan informasi keuangan suatu perusahaan pada suatu periode akuntansi yang dapat digunakan untuk menggambarkan kinerja perusahaan tersebut.

\section{e. Pengertian Laravel}

Laravel adalah sebuah framework PHP yang dirilis di bawah lisensi MIT, dibangun dengan konsep MVC(model view controller). Laravel adalah pengembangan website berbasis MVP yang ditulis dalam PHP yang dirancang untuk meningkatkan kualitas perangkat lunak dengan mengurangi biaya pengembangan awal dan biaya pemeliharaan, dan untuk meningkatkan pengalaman bekerja dengan aplikasi dengan menyediakan sintaks yang ekspresif, jelas dan menghemat waktu.

\section{f. Pengertian Pengujian Perangkat Lunak}

Pengujian perangkat lunak adalah elemen kritis dari jaminan kualitas perangkat lunak dan merepresentasikan kajian pokok dari spesifikasi, desain, dan pengkodean. Sejumlah aturan yang berfungsi sebagai sasaran pengujian pada perangkat lunak adalah [6].

\section{g. Pengertian Black Box Testing}

Pengujian dilakukan menggunakan sekumpulan aktifitas validasi, dengan pendekatan black box testing. Black Box Testing adalah menguji perangkat lunak dari segi spesifikasi fungsional tanpa menguji desain dan kode program [2]. Pengujian dimaksudkan untuk mengetahui apakah fungsi-fungsi, masukan, dan keluaran dari perangkat lunak sesuai dengan spesifikasi yang dibutuhkan.

\section{METODE PENELITIAN}

Metode pengembangan yang digunakan dalam penelitian ini adalah metode Waterfall. Tahapan yang dilakukan pada metode Waterfall ditunjukkan pada Gambar 1. 


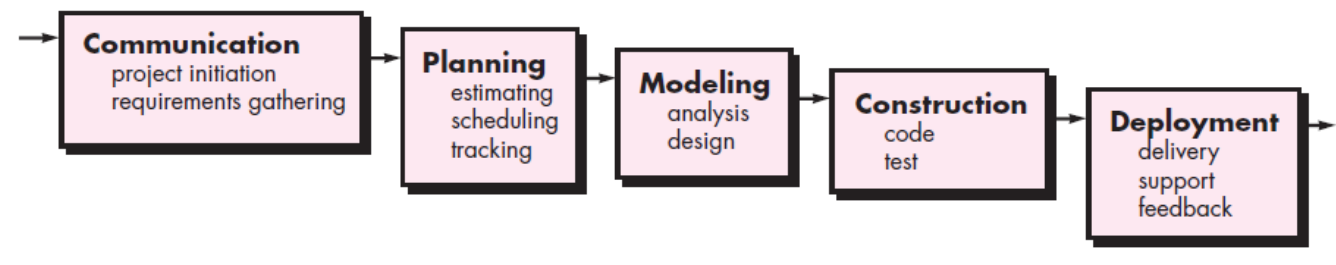

Gambar 2. Tahapan Waterfall Pressman [5].

Metode pengembangan sistem pada penelitian ini menggunakan metode Waterfall. Adapun tahap yang dilakukan yaitu :

1. Analisa Kebutuhan

Tahap ini dilakukan studi literatur dan komunikasi kepada pihak pengguna mengenai proses bisnis keuangan dan bagaimana sistem informasi yang diinginkan oleh pengguna. Hasil dari tahapan ini yaitu :

Kebutuhan Data :

a. Jenis-jenis aktifitas keuangan yang dilakukan oleh bendahara.

b. Data gaji karyawan.

c. Data kas kecil dan kas besar PT. Hulu Balang Mandiri.

d. Data penawaran gaji area kepada client.

e. Sistem dapat mencetak laporan arus kas.

Kebutuhan Antarmuka :

a. Sistem harus mempunyai antarmuka yang sederhana dan mudah digunakan.

b. Sistem mampu menampilkan data keuangan, baik data kas kecil maupun kas besar.

Kebutuhan Fungsional :

a. Sistem mampu mengelola pembuatan laporan keuangan bulanan dan tahunan.

b. Sistem mampu mengelola pembuatan laporan penawaran gaji area.

Dari data yang diperoleh, terdapat dua level login yang dibutuhkan untuk membedakan hak akses kedalam sistem. Hak akses kedalam sistem dapat dilihat pada use case diagram pada Gambar 2. 


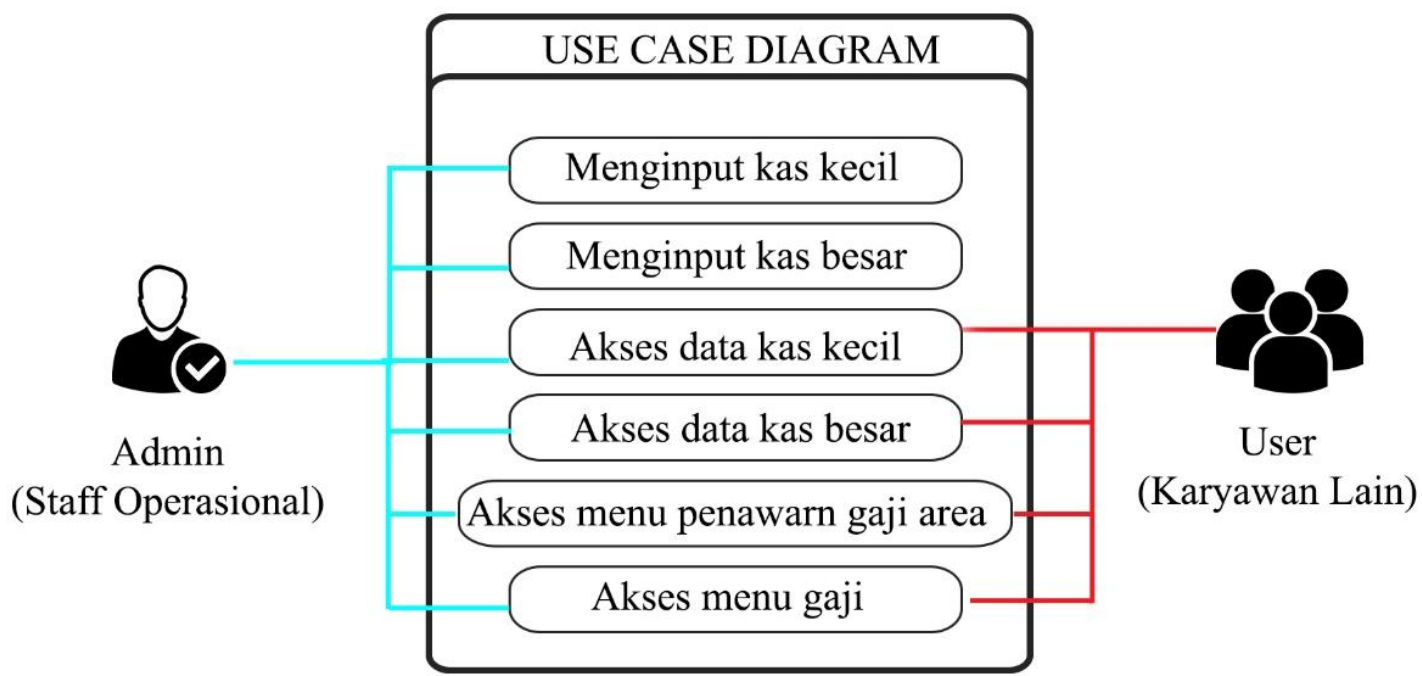

Gambar 3. Use Case Diagram.

Pada Gambar 2 dapat dilihat bahwa ada dua level user yang berbeda. User tersebut dapat melakukan hal seperti berikut:

a. Admin

Admin adalah administrator keuangan atau staff operasional PT. Hulu Balang Mandiri.

Admin dapat mengelola data kas kecil, kas besar, dan juga penawaran gaji area.

b. User

User adalah karyawan lain seperti manager keuangan PT. Hulu Balng Mandiri.

2. Desain Sistem

Dalam Desain sistem dilakukan desain UML dan Desain interface sistem.

a. Activity Diagram input data kas

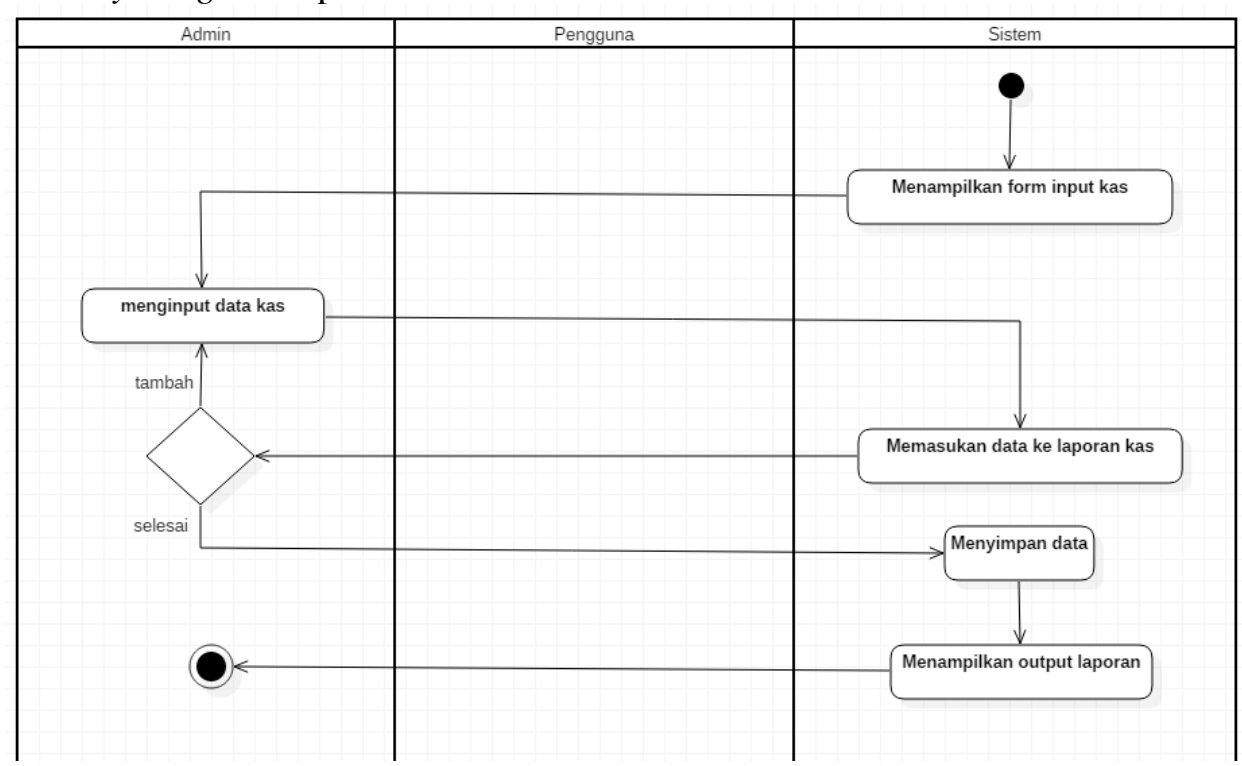

Gambar 4. Activity diagram input data kas. 
C2019 Ilmu Komputer Unila Publishing Network all right reserve

b. Activity Diagram akses menu kas

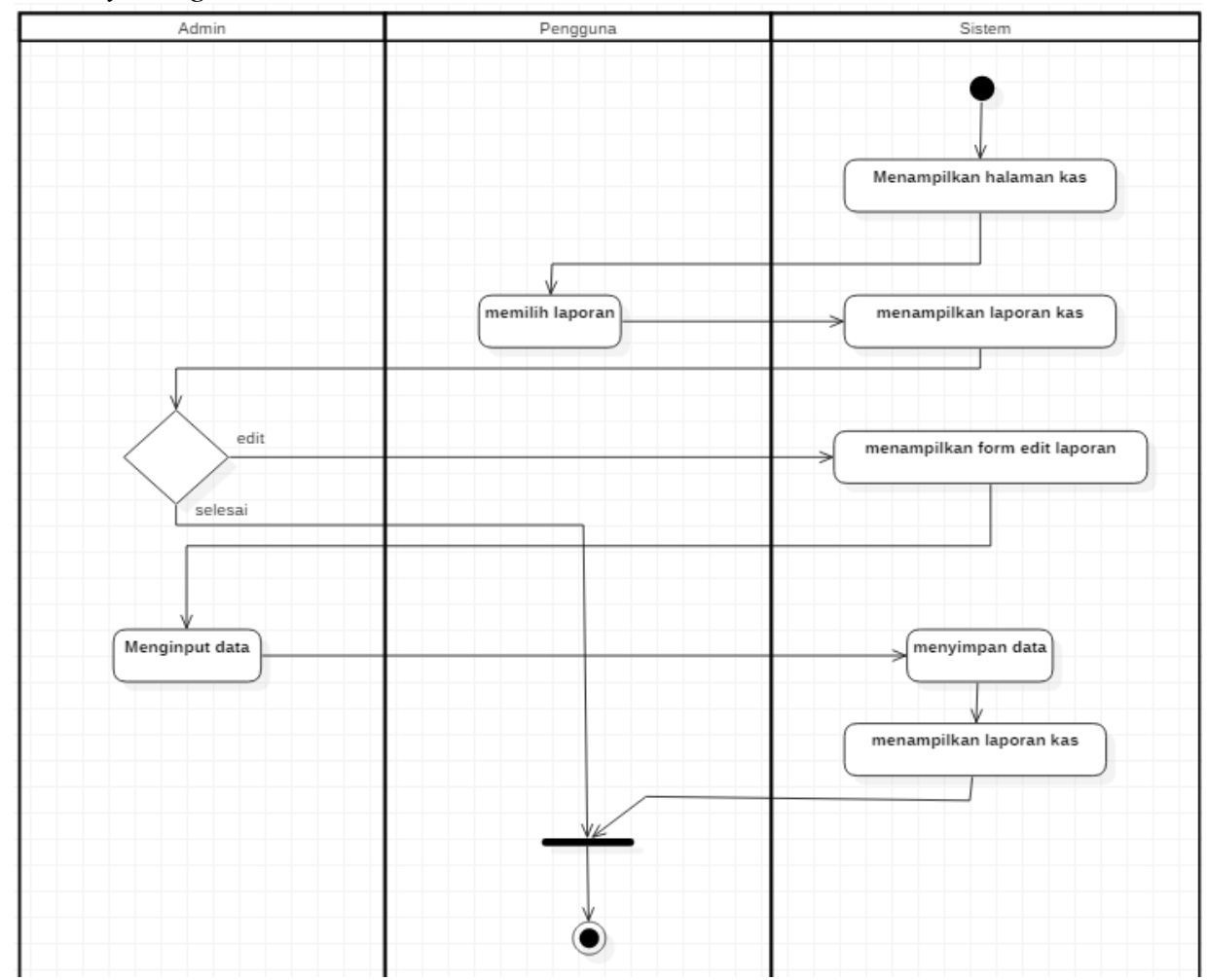

Gambar 5. Activity diagram akses menu kas.

c. Activity Diagram Penawaran Gaji Area

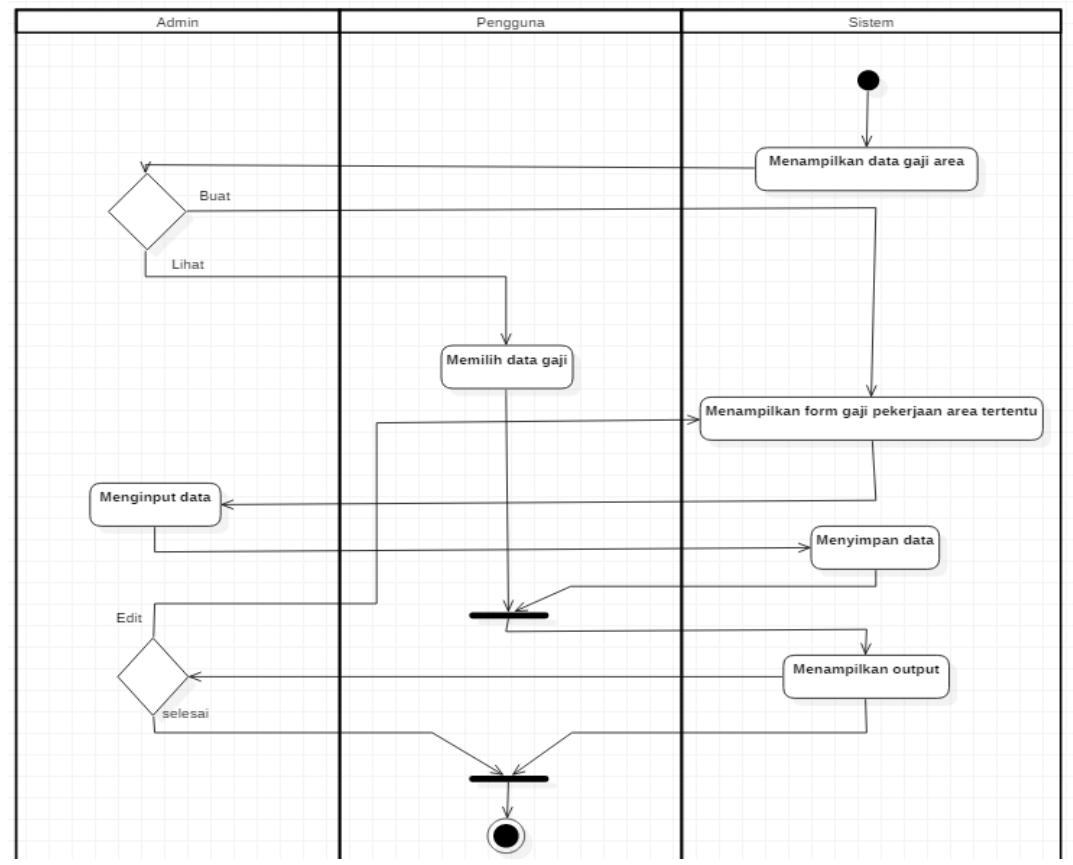

Gambar 6. Activity diagram penawaran gaji area. 


\section{PEMBAHASAN}

1. Implementasi

Tahap ini dilakukan implementasi dengan membuat kode program menggunakan Bahasa PHP dan framework Laravel. Hasil dari tahap kode program ditunjukkan dengan beberapa tampilan dengan penjelasan masing-masing fitur sebagai berikut :

a. Input Kas

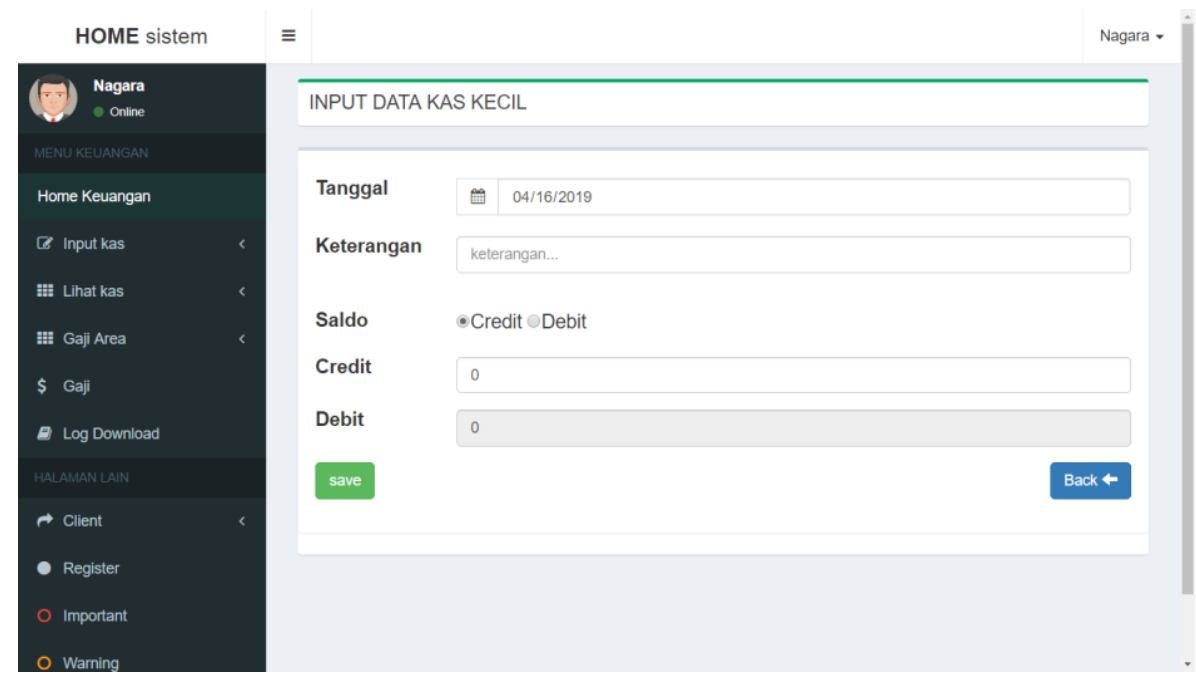

Gambar 7. Tampilan input kas.

Pada Gambar 6 menunjukkan tampilan inputkas kecil. Hanya level login admin yang dapat mengakse menu ini.

b. Menu Kas Kecil
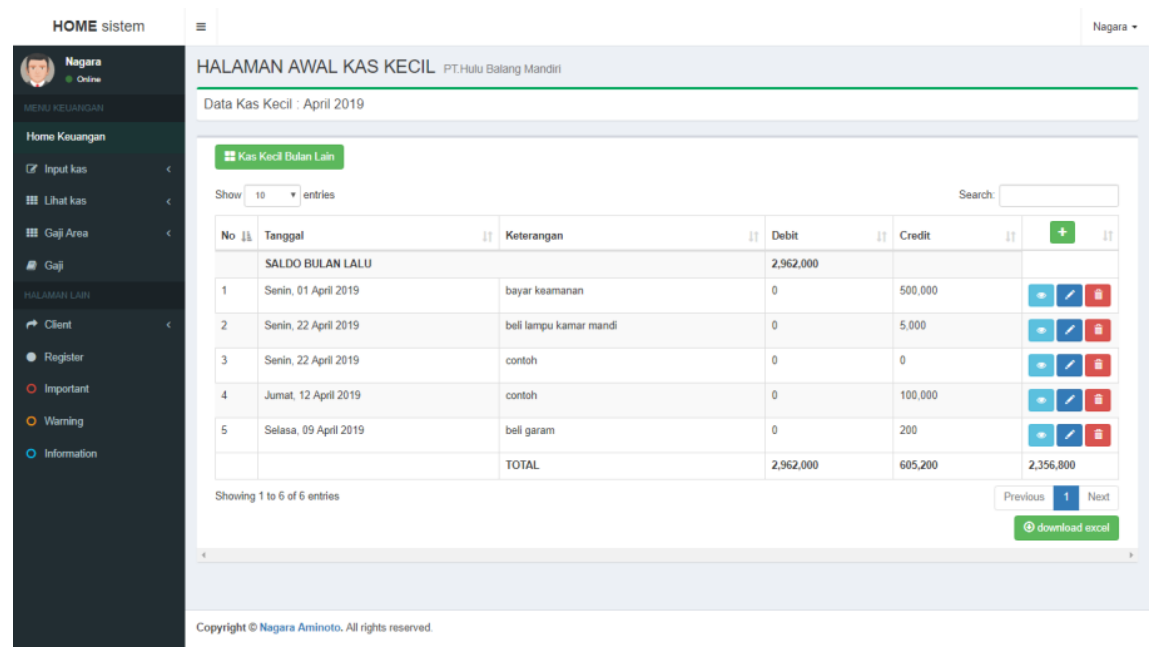

Gambar 8. Tampilan menu kas kecil.

Gambar 7 menunjukan halaman awal kas kecil. Pada menu ini ditampilkan data kas kecil dari bulan yang sedang berlangsung. admin dapat mengedit atau menghapus data pada tabel. Terdapat juga tombol untuk mendownload laporan dalam bentuk spreadsheet. Pada bagian atas terdapat tombol untuk menuju ke halaman dimana pengguna dapat melihat laporan kas kecil di bulan-bulan lain. 
c. Menu Kas Besar

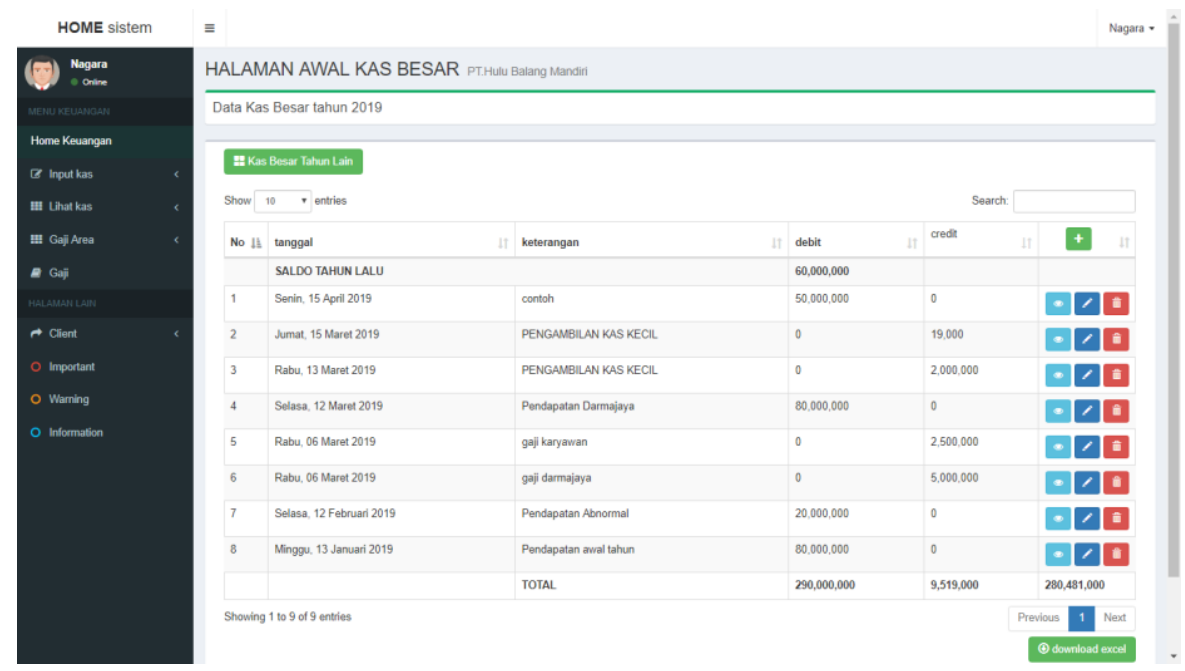

Gambar 9. Tampilan menu kas besar.

Gambar 8 menunjukkan halaman awal kas besar. Pada menu ini ditampilkan data kas besar dari tahun yang sedang berlangsung. admin dapat mengedit atau menghapus data pada tabel. Terdapat juga tombol untuk mendownload laporan dalam bentuk spreadsheet. Pada bagian atas terdapat tombol untuk menuju ke halaman dimana pengguna dapat melihat laporan kas besar di tahun lain.

d. Menu Penawaran Gaji Area

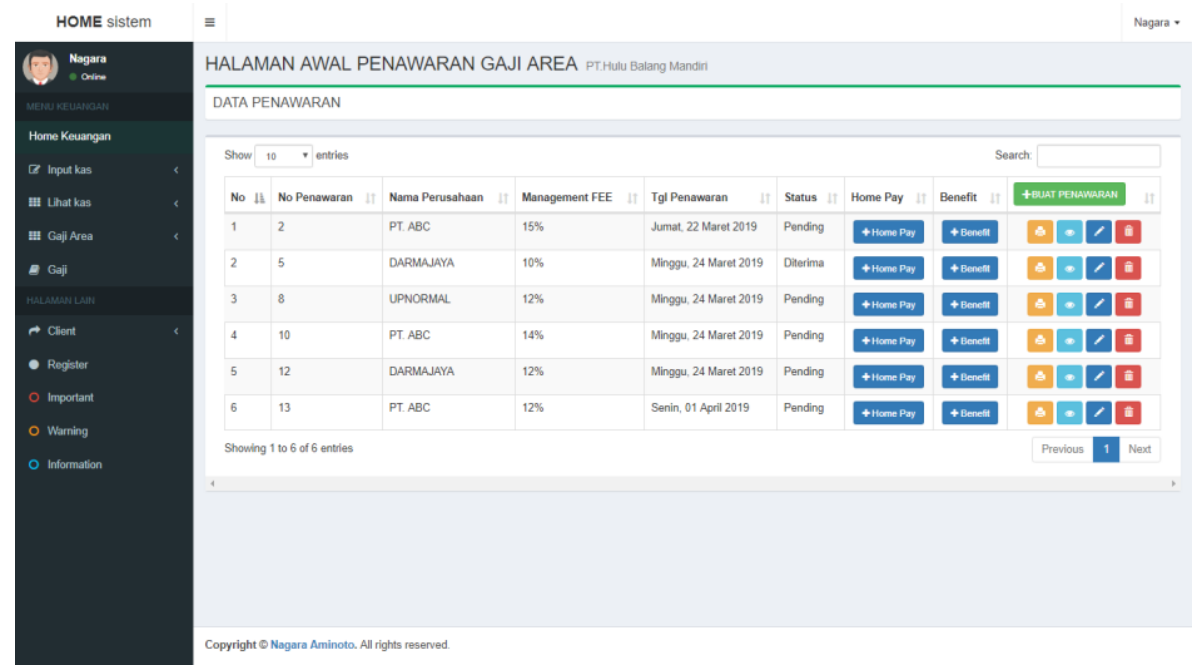

\section{Gambar 10. Tampilan menu penawaran gaji area.}

Gambar 9 menunjukkan halaman penawaran gaji area. Pada halaman ini terdapat tabel berisi penawaran gaji area terhadap client maupun calon client. Penawaran dibuat dengan menekan tombol buat penawaran, lalu mengisi bagian home pay dan benefit. Output dari pembuatan penawaran dapat dilihat dengan menekan tombol dengan icon mata pada data tabel. Tampilan lihat detil penawaran dapat dilihat pada Gambar 10. 


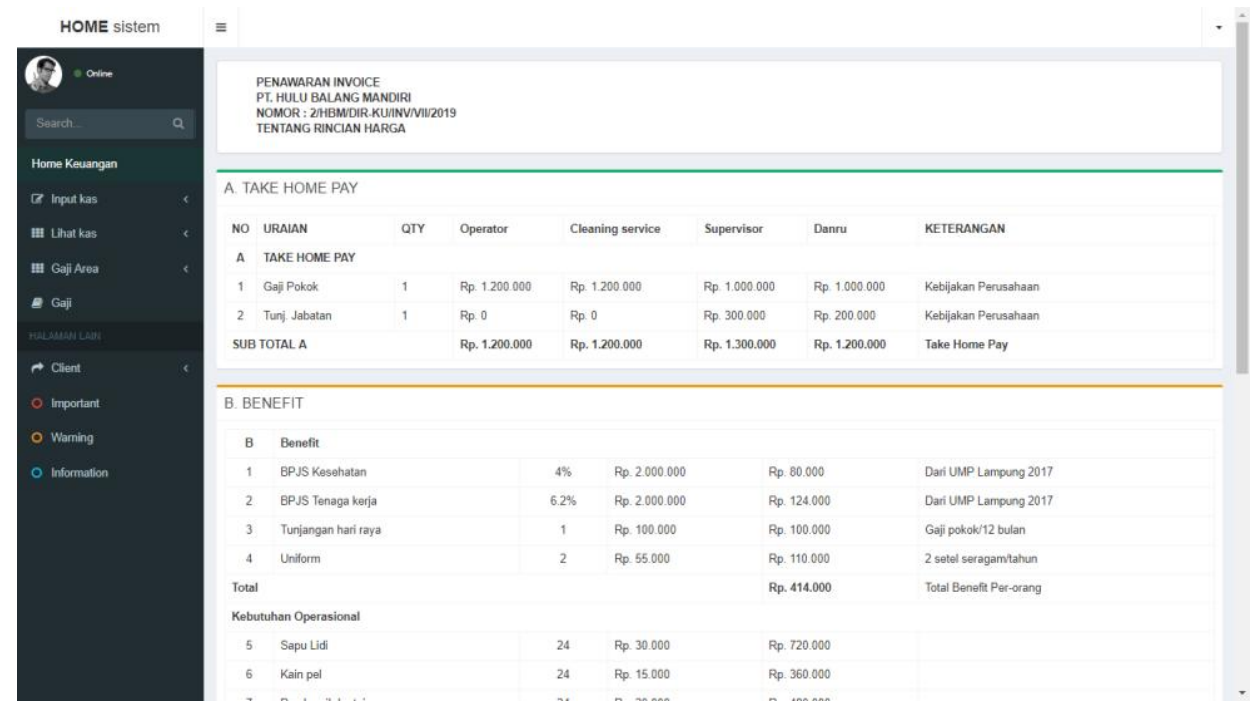

Gambar 11. Tampilan detil penawaran.

2. Pengujian Program

Tahap ini dilakukan pengujian terhadap sistem, pengujian dilakukan mengenai fungsionalitas program (black box testing) dan uji validitas sistem bersama pihak PT. Hulu Balang Mandiri. Sistem telah diuji bersama staff operasional perusahaan pada pengguna level admin dan juga user.

Pengujian dilakukan dengan menguji login, tampilan, ketepatan data, ketepatan dataset diagram, fungsionalitas tombol, level login user, dan tampilan pada perangkat mobile. Dari 130 kasus yang diuji hasil pengujian menyatakan sistem telah sesuai dengan kebutuhan dan permintaan perusahaan. Beberapa catatan hasil pengujian yang telah dilakukan kepada pihak perusahaan, penguji menyarankan untuk menambahkan fitur chat untuk mempermudah komunikasi antar karyawan. Pihak perusahaan juga menyarankan untuk menambahkan fitur artificial intelligence untuk pengambilan keputusan berdasarkan data keuangan.

\section{SIMPULAN}

Dari hasil penelitian yang dilakukan, dapat diambil simpulan sebagai berikut.

1. Telah berhasil dikembangkan sistem informasi manajemen keuangan pada PT. Hulu Balang Mandiri berbasis web menggunakan framework laravel untuk memudahkan karyawan PT. Hulu Balang Mandiri dalam memanajemen keuangan dan berbagi informasi keuangan.

2. Sistem informasi ini telah berhasil menampilkan informasi keuangan meliputi: diagram pengeluaran kas kecil, diagram saldo perusahaan per bulan, diagram saldo perusahaan per tahun, laporan kas kecil, laporan kas besar, dan informasi penawaran gaji area untuk membantu karyawan dalam pengambilan keputusan, manajemen data keuangan, dan membuatpenawaran.

3. Hasil pengujian black box sistem informasi manajemen keuangan pada PT. Hulu Balang Mandiri menunjukkan bahwa sistem berfungsi sesuai kebutuhan pengguna. 


\section{DAFTAR PUSTAKA}

[1] Azali, C. 2016. "Cashless in Indonesia Gelling Mobile E-Frictions?”, Journal of Southeast Asian Economies. vol. 33 no. 3 (2016), pp. 364-86.

[2] A.S Rosa dan Salahuddin M. 2011. Modul Pembelajaran Rekayasa Perangkat Lunak (Terstruktur dan Berorientasi Objek). Bandung: Modula.

[3] DeMott, D.L. 2014. "Human Reliability and the Cost of Doing Business". vol. 12 no. 4 (2014), pp. 3-1.

[4] Hariyanto, B. 2004. Sistem Manajemen Basis Data, Informatika. Bandung.

[5] Pressman, R.S. 2015. Rekayasa Perangkat Lunak: Pendekatan Praktisi Buku I. Yogyakarta: Andi.

[6] Sukamto, Ariani, dan Rosa. 2009. Langkah-langkah Pengujian Perangkat dan Evaluasi Piranti LuPiranti Lunak.

[7] Sutabri, T. 2012. Konsep Sistem Informasi. Yogyakarta: Andi.

[8] Sutanta, E. 2011. Basis Data dalam Tinjauan Konseptual. Yogyakarta: Andi.

[9] Teknologi.id. 2018. Jumlah Pengguna Smartphone di Seluruh Dunia dari 2014-2020, (https://teknologi.id/insight/jumlah-pengguna-smartphone-di-seluruh-dunia-dari-20142020/) 